\title{
Distance Learning: Vector of Present-day Educational Paradigm
}

\author{
Donina I.A. \\ Yaroslav-the-Wise Novgorod State University, \\ Veliky Novgorod, Russia \\ doninairina@gmail.com
}

\author{
Donina E.E. \\ Yaroslav-the-Wise Novgorod State University, \\ Veliky Novgorod, Russia, \\ Katarine2531@yandex.ru
}

\author{
Khachaturova K.R. \\ State Budgetary Educational Institution Secondary School No. 129, \\ of the Krasnogvardeisky district of St. Petersburg, \\ St. Petersburg, Russia \\ ekaterina.tnu@mail.ru
}

\begin{abstract}
The article examines the trends, problems and prospects for the introduction of distance learning in the modern educational process. The complex of information technologies provided by remote access platforms creates a unified educational environment where one user (a group of users) helps another (others) to achieve the desired through quick access directly from the working place; it will be possible to study efficiently when it is necessary and in any suitable moment. Distance learning, based on the new technologies and using the latest ICT, is one of the promising innovative directions that personify the global revolution in the development of mankind. In addition, the rapid and often unforeseen changes in the development of society constantly dictate new requirements for the content and forms of knowledge transfer. This wave brings new pedagogical technologies based on various types and forms of distance learning and gaining more and more popularity. It is this learning context that modern education researchers consider a prospect for the development of management systems for actively developing knowledge. The article analyses the Russian and international scientific research ideas and highlights the main principles and forms of distance learning. An empirical analysis of the current situation of distance education at school is carried out. The directions for the development of this technology have been worked out to improve the quality of education in the context of lifelong education of the individual.
\end{abstract}

Keywords-distance learning, information environment, education for life, innovative educational technologies, digitalization of education, educational platforms

\section{INTRODUCTION}

A human living in the modern information society is considered a creative, resourceful, proactive, and constantly developing person who is in harmonious relations with the environment and other people [1]. It is quite obvious that the industrial civilization is being replaced by a super-industrial society, when knowledge and information become the main value and driving force of progress; the computer and high information technologies become its main tool and symbol [2].

The use of information and communication technologies (ICT) in education today is associated with a number of administrative, economic, educational, psychological, and financial problems. Many researchers see their solution in the modeling of information and educational environment, taking into account new technologies, methods, and teaching aids [3]. At the same time, pedagogical diagnostics remains an important component in the development of ICT models.

Distance learning, as a subtype of continuous educational process and, at the same time, a modern form of educational activities, provides ample opportunities in the field of education. However, the methods and tools that have long been effectively used in distance learning in many parts of the world have not yet been fully implemented in Russia. Having analyzed the ideas of 39 researchers from 13 countries, J. Baggley and T. Belawati described the main successes and failures of distance learning, as well as the reasons that caused them. Their work presents various contexts of this educational technology and the development of distance learning in Asia. The authors give valuable recommendations that can be successfully implemented and can contribute to solving the most important socio-economic problems not only in Europe and Asia, but also in all regions of the world [4]. It is evident that modern distance learning technologies which use the latest means of communication are aimed at the development of the student's personality and active inclusion of a student in the educational process. In their research D.R. Harrison [5], T. Anderson [6], and other scientists describe in detail the structure of the work carried out in the field of online learning. The concept of a new type of education goes far beyond providing access to information [6]. It focuses on the elements of educational experience that contribute to the creation of communities of learners actively participating in joint creative 
research, since creative thinking is the engine of science and the key to progress [7]. The basis of distance learning is the creation of an innovative and renewable educational environment based on open, but purposeful communication [8]. The essential elements of this process are the social, cognitive, and pedagogical presence of all participants [9].

\section{PROBLEM STATEMENT}

However, the context of distance learning, where all contacts and activities are mediated, creates a unique example of digitalization not only of education, but also of social, professional, and cultural interaction and development. In this regard, scientists are concerned about two main problems:

1) What problems does the educational environment face in the transition to innovative forms of education, and what difficulties may arise in the future?

2) How can one cope with the difficulties in distance interaction of participants in the educational process in order to maintain the sustainability of this learning model?

A similar problem was identified after the practical transition to distance learning showed the inconsistency of initial expectations and optimistic forecasts [6]. Now distance learning allows independently choosing the place, time, and pace of learning. In addition, this is an excellent opportunity to receive quality education for people who are deprived of the access to traditional education for various reasons. At the same time, a number of researchers note the presence of significant problems and aspects in distance learning that have a destructive effect on the educational system as a whole [5].

We can distinguish the following main factors among those that determine the need and feasibility of a wider introduction of distance learning into the present-day educational process:

- the growing need of society in informal education, in renewal and development of lifelong learning technologies;

- the transformation of needs in communication and information transfer. Nowadays people have significantly changed their ideas about the methods of obtaining and applying knowledge due to the development of communication in social networks, the emergence of new multimedia products, the digitalization of databases, etc.;

- the need to practice a free choice [10].

O.V. Dubinina substantiates the need to use a series of criteria in assessing the feasibility of introducing distance learning in an educational institution. The author points out the importance of an integrated approach that takes into account the specifics of students, the financial and methodological support of the process, the level of teachers' readiness to use Internet technologies, the availability of the necessary competencies, etc. [11].

Thus, the analysis of the available research in the field of distance learning has revealed the main problem: what are the trends and prospects for the implementation of various forms of distance learning in modern Russian society?

\section{RESEARCH QUESTIONS}

Among the main research questions, the following were highlighted:
- Justification of the feasibility and necessity of introducing distance learning forms in a modern school.

- Identification of the problems faced by society, teachers, and students during the implementation of distance learning and the search for methods and means of solving the problems.

\section{PURPOSE OF THE STUDY}

The research purpose was to study the attitude of the educational process participants to the implementation of distance learning and to describe the main prospects for modernizing the educational environment using digital technologies.

\section{RESEARCH METHODS}

The research methods used are as follows:

- theoretical analysis of the Russian and international research sources (analysis, synthesis, generalization);

- empirical research with the help of survey methods;

- mathematical statistics methods to process the data received.

Within the research frame, a survey was conducted of 200 students of grades 8-11, 100 parents and 30 teachers of the State Budgetary Educational Institution of School No. 129 in St. Petersburg, on the use of distance learning and problems connected with its implementation in the educational process.

\section{FINDINGS}

The results of the survey are:

- $60 \%$ students and $42 \%$ of teachers have a positive attitude to distance learning, while only $17 \%$ of parents showed a positive reaction.

- $40 \%$ of children have a broad understanding of the distance learning possibilities and actively use them to satisfy their cognitive processes. The percentage of teachers proficient in various distance learning forms was $65 \%$. Parents only partially have an idea of all the possibilities of distance technologies (12\%).

- $35 \%$ of school students have an intrinsic motivation to implement distance learning. At the same time, other $35 \%$ consciously join the educational process at the request of the teacher. $28 \%$ of teachers are inclined to self-development and implementation of distance learning. Summarizing the results showed the following trend (Fig. 1).

As one can see from the figure, teachers and students are generally positive about the introduction of distance learning. Parents, however, mention more negative factors than positive ones.

So, among the negative factors, parents single out:

- Difficulties with ensuring constant access of the child to educational resources $(70 \%)$.

- Limited opportunities for direct communication with the teacher in case of difficulty with the perception of the content $(66 \%)$. 
- Decreased motivation of children to actively study the content $(58 \%)$.

- Lack of possibility to implement objective quality control of the acquired knowledge (53\%).

- An increase in the time required to learn a certain amount of content (46\%).

- Lack of a clear algorithm for working with educational resources $(27 \%)$.

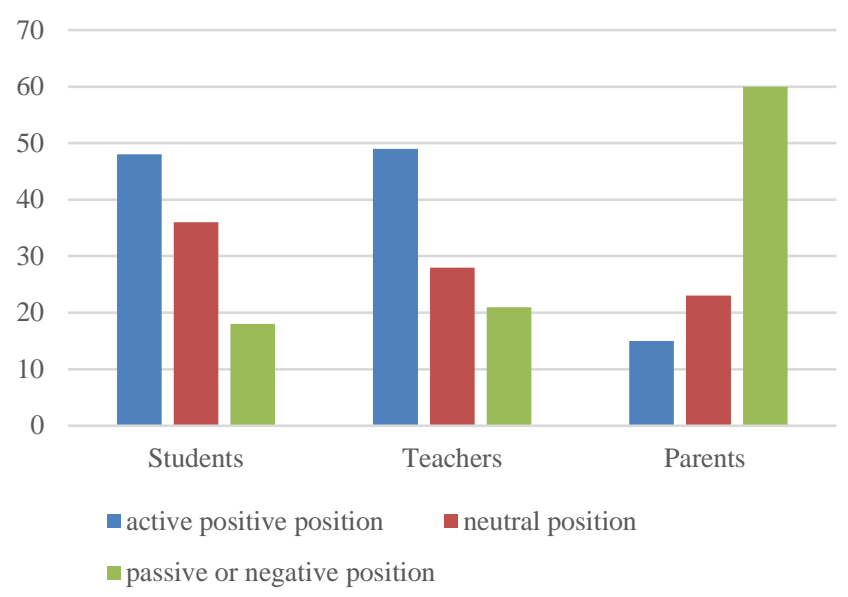

Fig. 1. The attitude of educational process participants to distance learning

Meanwhile, a fairly high percentage of teachers (23\%) and students $(15 \%)$, who are negative about the introduction of distance learning, testifies to real difficulties in its implementation.

The reasons for the negative answers of teachers were:

- Insufficient theoretical and methodological training of the teacher for the implementation of distance learning $(63 \%)$.

- Low provision of opportunities for free access to educational platforms at a certain time for all participants in the process $(45 \%)$.

- Lack of uniform requirements and practical developments in the field of distance learning (27\%).

- Lack of material and technical support of the process $(22 \%)$.

The students reported as main difficulties the impossibility of obtaining high-quality personal help from the teacher in understanding incomprehensible moments of the content $(80 \%)$ and lots of time spent for searching the necessary information on various resources $(67 \%)$.

Today, taking into account the specific features of the economic and political situation, the occurrence of unforeseen situations (lockdown, emergencies, etc.), the uninterrupted character of educational process acquires the utmost importance.

A survey of the educational process participants showed the most popular resources in Russian schools:

- Dnevnik.ru (used by $89 \%$ of teachers and $80 \%$ of students);
- "Russian Electronic School" resh.edu.ru (75\% of teachers and $60 \%$ of students);

- Yaklass (63\% of teachers and $52 \%$ of students);

- Uchi.ru (58\% of teachers and $45 \%$ of children);

- Moodle (33\% of teachers and $21 \%$ of students);

- Google classroom (28\% teachers and $21 \%$ students);

- iSpring Online (23\% of teachers and $21 \%$ of children);

- Platform of the New School (18\% of teachers and $15 \%$ of students).

In addition, school web-sites (95\% of teachers and $70 \%$ of school students), teachers' blogs (57\% of teachers and $38 \%$ of students), social network VKontakte, etc. (43\% of teachers and $36 \%$ of school students) are actively used in the educational process (Fig. 2).



Fig. 2. Rating of distance learning platforms used in Russian schools

At the same time, as the study reveals, one school or one teacher often uses different educational platforms and resources for teaching and uses several channels of communication with students (phone, Viber, e-mail, teacher's blog, website, etc.).

A peculiar feature of distance learning at the present stage is that teachers of one educational institution use different educational resources, which (according to parents and students) significantly complicates learning and increases the time spent on organizing cognitive activities [12].

In addition, the research shows that the percentage of students using all educational platforms is lower than that of educators. It indicates that all students are not actively involved in learning and do not regularly get in touch with the teacher. As a result, it negatively affects the quality of knowledge.

At the same time, the low activity of a student is not always associated with a reluctance to learn [13]. Since today one of the pressing problems is the socio-economic factor (lack of a computer or the Internet at home, several children in a family with limited technical means, a low level of information competence of schoolchildren and a lack of relevant information about all the possibilities and features of distance 
learning, etc.). Thus, the research allowed identifying a number of positive aspects that confirm the perspective of introducing distance learning into a modern school. However, it also revealed a number of difficulties and shortcomings of the implementation of this form of education in the present-day socio-economic situation.

Summarizing the results outlines the main directions of work to be carried out to optimize the introduction of distance learning in today's reality.

It is important to take into account that presently the provision and dissemination of educational services performs not only a socio-cultural, but also an economic function. The active use of social networks, the creation of texts and images, editing, search and retrieval of information, its processing and transmission should be the basis not only for the acquisition of new knowledge and the formation of ideas and a system of ideological attitudes, they should become the basis for the development of professional skills in any field.

In the context of the problem under consideration, it should be noted that today society is on the verge of transition to a completely new type of distance learning, which is characterized by a global scale and a wide range of functions performed. This new type presupposes the integration of radio, television, computer, satellite and cable communication devices which provide the fastest possible transfer of significant amounts of information anywhere in the world and the possibility to quickly receive feedback from many consumers [10].

The range of available educational resources is wide enough and new platforms are added every day. M.S. Borba, A.S. Chiari et al studied the possibilities of such information and communication systems and virtual technologies as Vive VR, Daydream, Moodle, etc. The researchers clearly demonstrate how this content helps to organize electronic, synchronous and asynchronous learning for students of different ages. In addition, researchers provide examples of online tasks that allow monitoring student progress [14].

Various options for organizing distance learning are described by V. Al-Rami, who proves that the intensity of communication between participants of the educational process can be modified depending on the method of providing information, including full-time and blended courses. Satisfaction with dialogue and interaction during the distance learning is the main factor in assessing the effectiveness of the resource by students [15].

It should be noted that during the transition to a new level of distance learning it is important to use innovative forms of providing educational content and knowledge control. Video presentations and lectures, online lessons and virtual demonstrations that were common in the early stages are no longer sufficient to ensure the quality of education. Thus, priority in organizing distance learning is given to various forms of joint educational activities: discussions, research projects, online quests, etc. During joint work, students not only seek information on their own, but also can explain the educational content to each other, while simultaneously working together to understand and consolidate it.

Today, electronic educational resources provide a wide range of forms and methods of innovative learning, including: computer modeling, simulator games, web quests, as well as virtual learning environments, cloud services, mobile systems, MOOCs, etc.

However, the introduction of distance forms should be carried out on the basis of a thorough analysis of the existing conditions of the region, educational institution, and teaching staff. Considering the possibilities and needs of training, the social and economic situation, the availability of electronic resources and the availability of means of operational feedback from educational process participants, one can choose both the forms and types of distance learning and define its share in the structure of educational activity.

\section{CONCLUSION}

Presently, the paradigm of education development is directly related to the introduction of distance learning forms at all stages of the educational process. This system is becoming one of the structures of lifelong learning without restrictions on age and degree of training, territorial and economic aspects. With the help of distance educational technologies, each process participant can change the pace and nature of the programs' mastering, can construct an individual educational route, taking into account personal characteristics, abilities and capabilities.

In the State Program of the Russian Federation "Development of Education", e-learning is regarded as one of the major directions of education modernization in order to increase the potential of human resources. Many educational institutions of the country have chosen to modernize the forms and methods of teaching, giving one of the leading roles to distance learning. Meanwhile, the informational and personal competence of the student creates the basis for the transition to a qualitatively new level of education; the educational environment should place the child in the situations that contribute to the development of both a system of knowledge and ideas and practical skills of their application.

Analysis of theoretical and empirical research data allows concluding that distance learning can become one of the most effective and demanded technologies to implement the principle of lifelong education.

Distance learning best meets the requirements of the time which is characterized with a predominance of competitive, market foundations, free work schedule, rapidly changing needs of society and perspectives of socio-economic development. In addition, distance technologies in education are the means that will successfully solve the problems of forming a creative personality, its development, and self-realization.

Today, one of the main problems of distance learning is the methodology of using distance technologies with the due regard to the individual approach, a large amount of information, various forms of visualization, differentiation of the educational process and teaching aids. In the distance learning environment, a student gets the opportunity to follow an individual educational route.

At the same time, distance learning programs are focused on a high level of self-awareness and motivation for self-education and lead to the development of a modern, independent, and creative personality capable of living in a new civilization. 


\section{References}

[1] K.R. Khachaturova, "Theoretical Grounds Of Teaching In Adolescence", Components of Scientific and Technological Progress, 2013, 2(36), pp. 29-31.

[2] M.N. Pevzner, R.M. Sheraizina, I.A. Donina, P.A. Petryakov and N.V. Aleksandrova, "Marketing-Related Activity In A Heterogeneous Educational Organization”, Revista Espacios, 2017, vol. 38(40), pp. 2943.

[3] M. Pevzner, A. Shirin, N. Shaydorova and A. Rakhkochkine, "Internationalization of Schools in Russia", Policy Futures in Education, 2019, vol. 17(6), pp. 715-731. https://doi: 10.1177/1478210319828940

[4] J. Baggaley and T. Belawati, "Distance Education Technologies in Asia", SAGE Publications Pvt. Ltd., 2010380 p. Retrieved from: https://us.sagepub.com/en-us/nam/distance-education-technologies-inasia/book235938

[5] D.R. Garrison, "E-Learning in the 21st Century: A Community of Inquiry Framework for Research and Practice (3rd Edition)", London: Routledge/Taylor and $\quad$ Francis, 2017. https://doi.org/10.4324/9781315667263

[6] T. Anderson and P. Rivera-Vargas, "A Critical Look At Educational Technology From A Distance Education Perspective", Digital Education Review, 2020/06/30 208-229. DOI: 10.1344 / der.2020.37.208-229

[7] K.R. Khachaturova, "The Model Of The Educational Process To Develop The Capacity For Creativity In Schoolchildren", Components of Scientific and Technological Progress, 2016, vol. 3(29), pp. 30-34.

[8] O.U. Pisnova and I.A. Martyshevskii, "Distance Learning Is A New Vector In Development Of Additional Education [Distantsionnoye obucheniye novyy vektor razvitiya dopolnitel'nogo obrazovaniya]", Pedagogy today: problems and solutions: materials of the IV international conference. scientific Conf. (Saint Petersburg, October 2018), 2020, Saint Petersburg: Svoye Izdatelstvo, 2018, pp. 34-38. Retrieved from: https://moluch.ru/conf/ped/archive/308/14546/

[9] G. Aimicheva, Z. Kopeyev, Z. Ordabayeva, N. Tokzhigitova and S. Akimova, "A Spiral Model Teaching Mobile Application Development
In Terms Of The Continuity Principle In School And University Education", Education and Information Technologies, vol. 25(3), pp. 1875-1889. https://doi.org/10.1007/s10639-019-10051-z

[10] A.V. Solovov and A.A. Menshikova, E-Learning: A Vector Of Development [Elektronnoe obuchenie: vektor razvitiya], Higher Education in Russia, 2015, vol. 11. Retrieved from: https://cyberleninka.ru/article/n/elektronnoe-obuchenie-vektor-razvitiya

[11] O.V. Dubinina and L.D. Hrytsiak, "Formation Model of Future Progect Managers Information Culture", American Journal of Engineering Research (AJER), 2019, vol. 8(2), pp. 72-77. Retrieved from http://lib.iitta.gov.ua/id/eprint/718843

[12] N. Kerimbayev, J. Kultan, S. Abdykarimova and A. Akramova, "LMS Moodle: Distance International Education In Cooperation Of Higher Education Institutions Of Different Countries", Education and Information Technologies, 2017, vol. 22(5), pp.2125-2139. DOI: 10.1007 / s10639-016-9534-5

[13] M. Helsen, W. Vollebergh and W. Meeus, "Social Support from Parents and Friends and Emotional Problems in Adolescence", Journal of Youth and Adolescence, 2000, vol. 29(3), pp. 319-335. DOI: https://doi: 10.1023/A:1005147708827

[14] M.C. Borba, A.S. Chiari and H.R.F.L. de Almeida, "Interactions In Virtual Learning Environments: New Roles For Digital Technology", Educational Studies in Mathematics, vol. 98, pp. 269-286. DOI: 10.1007/s10649-018-9812-9

[15] W. Al-Rahmi, "Examining Students' Satisfaction And Learning Autonomy Through Web-Based Courses", International Journal of Advanced Trends in Computer Science and Engineering, vol. 9(1), January - February 2020, pp. 356 - 370. DOI: 10.30534 / ijatcse / 2020 / 3491.22020

[16] P. Hills, and M. Argyle, "The Oxford Happiness Questionnaire: A Compact Scale For The Measurement Of Psychological Well-Being", Personality and Individual Differences, 2016, vol. 33(7), pp. 1073-1082. https://doi.org/10.1016/S0191-8869(01)00213-6 